\title{
ANALISIS KEPUASAN PELANGGAN DALAM BELANJA ONLINE: SEBUAH STUDI TENTANG PENYEBAB (ANTECEDENTS) DAN KONSEKUENSI (CONSEQUENTS)
}

\author{
Asmai Ishak \\ Fakulas Ekonomi Universitas Islam Indonesia \\ e-mail: asmai.ishak@uii.ac.id
}

\begin{abstract}
Abstrak
This study is aimed to analyze customer satisfaction in online shopping and its antecedents and consequences emerged. 300 consumers, who have shopped online and been selected through convenience sampling method, involved in the study. Questionnaires were adapted from the established research instrument and were tested before being spread to the respondents. Structural Equation Modeling was used to hypotheses. The results indicate that all of hypotheses are supported. This means that site characteristics of the online retailing such as the Shopping Convenience, the Site Design, the Informativeness, the Security, and the Communication drive the Customer Satisfaction which in turn affects positively the Commitment and the Word of Mouth Communication. The study also finds that the Word of Mouth Communication is not only driven by the Customer Satisfaction but also is encouraged by the Commitment. These findings strengthen and are consistent with the previous studies. The results of this study are very valuable marketers, especially who work in online retail business, in encouraging the word of mouth communications among their customers.
\end{abstract}

Keywords: Customer Satisfaction, Site Design, Informativeness, Security, Communication, Commitment, Communication Word of Mouth (WOM).

Studi ini bertujuan untuk menganalisa kepuasan konsumen dalam belanja online dengan faktor-faktor penyebab dan konsekuensi yang akan ditimbulkan dengan menggunakan konsumen ritel online sebagai subyek penelitian. Sampel penelitan ini berjumlah 300 responden. Instrumen penelitian berupa kuesioner, dikembangkan berdasarkan instrumen yang sudah dipakai oleh peneliti lain dan diuji validitas dan realibilitasnya sebelum diedarkan kepada responden penelitian ini. Structural Equation Modeling (SEM) dipergunakan untuk menguji hipotesa. Hasil analisis menunjukkan bahwa semua hipotesa penelitian ini terbukti. Dengan kata lain karakteristik situs seperti Kemudahan, Desain Situs, Keinformatifan, Keamanan, dan Komunikasi berpengaruh secara signifikan terhadap Kepuasan Pelanggan. Selanjutnya, Kepuasan Konsumen mendorong terciptanya Komitmen dan Komunikasi WOM. Hasil penelitian ini juga menunjukkan bahwa kegiatan Komunikasi WOM tidak hanya dipengaruhi secara langsung oleh Kepuasan tetapi dipengaruhi juga oleh Komitmen. Hasil penelitian ini memperkuat dan konsisten dengan temuan beberapa penelitian sebelumnya. Hal ini sangat bermanfaat bagi praktisi pemasaran dalam menyusun strategi pemasaran bisnis ritel online, terutama berkenaan dengan cara mendorong terciptanya komunikasi WOM.

Kata kunci: Kepuasan Konsumen, Kemudahan, Desain Situs, Keinformatifan, Keamanan, Komunikasi, Komitmen, dan Komunikasi Word of Mouth (WOM).

\section{PENDAHULUAN}

Perkembangan teknologi yang semakin canggih telah membawa perubahan pada masyarakat Indonesia, yaitu dengan adanya internet yang memungkinkan bagi seseorang untuk melakukan komunikasi dengan pihak lain tanpa di- batasi waktu dan jarak. Hal ini juga yang kemudian memengaruhi gaya hidup masyarakat Indonesia dengan adanya tren belanja online melalui internet. Dengan jumlah penduduk Indonesia yang mencapai 25 juta jiwa pada tahun 2008 dan diprediksikan akan meningkat 
sebesar 37\% hingga tahun 2010, juga dengan fakta bahwa pertumbuhan internet di Indonesia adalah yang terbesar ketiga di dunia menunjukkan besarnya peluang bisnis berbasis online baik untuk pemasar selaku penjual maupun konsumen yang akan membeli produk yang ditawarkan.

Kegiatan belanja online merupakan cara baru dalam melakukan transaksi. Dalam kegiatan ini pembeli dan penjual tidak bertemu secara langsung seperti halnya proses penjualan biasa. Efisiensi waktu dan juga efektifitas dalam proses transaksi merupakan hal yang membuat konsumen tertarik untuk melakukan belanja online. Penjual akan menggunakan internet untuk menampilkan situs yang mereka miliki sebagai toko dengan segala produk yang ditawarkan kepada konsumen. Kemudian konsumen sebagai pembeli juga akan melihat dan memutuskan untuk membeli produk yang ditawarkan melalui situs yang ada.

Banyaknya penjual yang menawarkan produk secara online memberi kesempatan konsumen untuk memilih sebelum memutuskan untuk membeli. Salah satunya adalah dengan membandingkan karakteristik satu situs penyedia produk dengan situs lain untuk produk yang sama. Berdasarkan kajian yang telah dilakukan, Chung and Shin (2010) mengidentifikasi lima atribut karaketistik situs yang dipertimbangkan konsumen dalam memutuskan pembelian yaitu kemudahan belanja, desain situs, keinformatifan, keamanan, dan komunikasi.

Kemudahan dalam belanja merupakan faktor penting dalam situs penjualan karena hal ini berkaitan dengan kenyamanan konsumen (Szymanski and Hise, 2000). Hasil penelitian Szymanski and Hise (2000) menunjukkan bahwa desain situs merupakan lingkungan fisik toko yang akan memberikan efek positif bagi konsumen untuk berbelanja. Disamping itu, tersedianya informasi secara lengkap tentang produk yang ditawarkan merupakan faktor lain yang sangat memengaruhi konsumen untuk melakukan pembelian (Jun and Chung, 2006). Sebuah situs juga harus memberikan jaminan keamanan bagi konsumennya dalam melakukan transaksi, seperti menjaga privasi konsumen dan pengiriman produk tepat waktu (Hoffman and Novak, 2000). Konsumen yang terbiasa melakukan transaksi online membangun informasi secara kolektif dengan pengguna internet lain, sehingga komunikasi termasuk satu karakteristik yang memengaruhi konsumen dalam membandingkan situs (Barlow et al., 2004).

Karakteristik diatas merupakan kunci bagi pemasar online dalam proses menciptakan kepuasan pelanggannya yang pada akhirnya akan memberikan keuntungan bagi organisasi (Reicheld and Sesser, 1990). Tingkat kepuasan konsumen yang tinggi atas transaksi yang dilakukan secara online cenderung akan meningkatkan komitmen konsumen mengingat kepuasan dan komitmen adalah dua faktor yang interaktif (Mukherjee and Nath, 2007). Namun demikian, kepuasan dan komitmen saja tidak cukup untuk menjaga keberlangsungan sebuah organisasi. Kepuasan dan komitmen yang bermuara pada komunikasi Word of Mouth (WOM). Komunikasi WOM akan mendorong pelanggan yang puas dan komit untuk merekomendasikan produk yang dikonsumsinya kepada orang lain. Kondisi tersebut akan mendorong terjadinya transaksi yang berkesinambungan sehingga dapat menjaga keberlangsungan organisasi tersebut untuk tetap eksis di pasar (Casalo et al., 2008).

Penelitian ini bertujuan untuk menganalisa faktor-faktor penyebab dalam berbelanja online seperti kemudahan belanja, desain situs, keinformatifan, kemananan dan komunikasi berikut konsekuensi yang dihasilkannya yaitu kepuasan konsumen dan dampaknya pada komitmen dan komunikasi WOM.

\section{KAJIAN PUSTAKA DAN HIPOTESA}

\section{Kemudahan}

Kemudahan pengguna situs mencerminkan detail informasi mengenai produk, baik barang atau jasa. Hal ini berpengaruh dengan kepuasan sebab jika situs sulit untuk dinavigasikan dan terdapat konten yang kurang relevan, maka pengguna akan mudah untuk pindah ke situs lain (Reichheld and Scheffer, 2000). Kemudahan adalah faktor penting dalam indutsri ritel serta bentuk belanja lainnya seperti katalog dan belanja online.

Konsumen yang memutuskan untuk belanja ritel online bertujuan untuk memperoleh kemudahan dalam melakukan transaksi (Torkzadeh and Dhillon, 2002). Menurut Ranganathan and Ganapathy (2002) dalam konteks Business to Consumer (B2C), situs harus dirancang dengan baik sehingga konsumen 
dapat cepat mendapatkan informasi produk yang diinginkan. Beberapa temuan empiris menunjukkan bahwa kemudahan akses situs belanja ritel online mampu meningkatkan kepuasan pelanggan (Szymaski and Hise, 2000; Srinivansan et al., 2002; dan Chung and Shin, 2008). Mengacu pada temuan tersebut, penelitian ini mengajukan hipotesa:

$\mathrm{H}_{1}$ : Kemudahan belanja ritel online akan memiliki efek positif terhadap kepuasan pelanggan

\section{Desain Situs}

Sebagai salah satu karakteristik situs yang menunjang penampilan sebuah ritel online, grafis atau gambar harus dibuat menarik agar konsumen yang mengunjungi situ tersebut akan tertarik untuk menjelajahinya (Lohse and Spiller, 1998). Elemen desain yang kurang menarik atau buruk dapat menimbulkan kebingungan dan akan mengurungkan niat konsumen untuk melakukan pembelian. Pastrick (1997) menyatakan bahwa berbelanja online dianggap menyenangkan dan memuaskan konsumen ketika desain situsnya rapi, navigasi yang mudah, dan cepat. Mengingat kerapian, kemudahan navigasi dan kecepatan situs dapat menghemat waktu dalam berbelanja, dan tidak menguras pikiran konsumen dalam melakukan transaksi.

Szymanski and Hise (2000) menyatakan bahwa navigasi, informasi produk, dan desain situs merupakan faktor penting dalam menciptakan kepuasan konsumen online. Pendapat ini didukung oleh penelitian yang dilakukan oleh Page dan Lepkowska-Whitc, (2002), Ranganathan dan Ganapathy, (2002), Loshe dan Spiller, (1998) yang menunjukkan adanya pengaruh desain situs terhadap kepuasan pelanggan. Berdasarkan kenyataan tersebut maka hipotesa penelitian ini:

$\mathrm{H}_{2}$ : Desain situs ritel online akan memiliki efek positif terhadap kepuasan pelanggan.

\section{Keinformatifan}

Janda et al. (2002) dan Szymanski and Hise (2000) menyatakan bahwa kualitas informasi adalah faktor penting dari kepuasan konsumen dalam belanja online (e-satisfaction). Kualitas informasi dari sebuah situs menggambarkan tinggi rendahnya tingkat keinformatifan dari situs tersebut. Dengan kata lain situs yang informatif mampu menyediakan informasi yang berkualitas. Cheung et al. (2008) menyatakan bahwa paling tidak ada empat dimensi dari kualitas informasi dari sebuah situs yang dipertimbangkan konsumen pada saat berbelanja online yaitu relevan, kekinian, akurat, dan komperhensif.

Informasi yang relevan merupakan factor yang sangat penting bagi konsumen dalam berbelanjaan online. Pada umumnya konsumen tidak membaca seluruh informasi yang tersedia dalam situs. Mereka cenderung untuk mencari informasi sesuai dengan yang mereka inginkan dengan cara cepat dan sedikit usaha. Oleh karenanya penyediaan informasi dalam sebuah situs sebaiknya singkat dan relevan (Nah and Davis, 2002). Hal yang sama dan perlu diperhatikan oleh pengembang situs adalah kekinian dari informasi yang disediakan. Semakin tinggi tingkat kekinian informasi yang tersedia, semakin banyak nilai tambah informasi tersebut bagi konsumen (Madu and Madu, 2002).

Akurasi sebuah informasi merujuk pada kehadalan informasi tersebut. Informasi yang akurat menunjukkan bahwa informasi tersebut benar (Wixom and Todd, 2005). Akurasi informasi merupakan unsur yang sangat penting bagi kredibilitas situs. Konsumen akan merasakan manfaat maksimal dari sebuah informasi, jika mereka menganggap bahwa informasi tersebut akurat (Cheung et al., 2008). Dimensi terakhir dari kualitas informasi adalah ke-komperhensif-an. Dimensi ini mengacu pada tingkat kelengkapan informasi yang tersedia. Cheung et al. (2008) menemukan bahwa semakin komplit informasi yang disediakan oleh sebuah situs, semakin tinggi manfaat yang akan diperoleh pengguna situs tersebut.

Uraian diatas menunjukkan bahwa keinformatifan sebuah situs dapat mendorong kepuasan konsumen dalam berbelanja online. Hal ini didukung oleh penelitian Chung and Shin (2010) yang menunjukkan bahwa semakin tinggi keinformatifan dari sebuah situs, semakin tinggi pula kepuasan pelanggan situs tersebut. Oleh karena itu, penelitian ini mengajukan hipotesa:

$\mathrm{H}_{3}$ : Keinformatifan ritel online akan memiliki dampak positif terhadap kepuasan pelanggan. 


\section{Keamanan}

Lee and Turban (2001) menyatakan, satu hal yang sering kali disebutkan mengapa kecil kemungkinan konsumen untuk melakukan pembelian online adalah karena rasa khawatir akan konsekuensi yang akan dihadapinya. Keamanan dalam berbelanja online merujuk pada keamanan secara teknologi seperti program yang menjaga privasi, mekanisme verifikasi, dan enkripsi (Mukherjee and Nath, 2007). Klang (2001) menemukan bahwa meskipun pemasar telah meningkatkan system keamanan dan privasi melalui pengembangan teknologi dan mekanisme tertentu, hal itu tidak mampu unt meningkatkan keyakinan konsumen untuk bertransaksi secara online. Sebaliknya Swaminathan et al. (1999) menunjukkan bahwa dengan dikembangkannya system pembayaran tertentu mengakibatkan konsumen tidak terlalu memperhatikan unsur keamanan dalam belanja online.

Terlepas persepsi tentang keamanan ini cukup beragam bagi konsumen, pemasar online perlu meyakinkan calon konsumennya bahwa transaksi yang mereka lakukan sangat aman. Udo (2001) menemukan bahwa 70 persen dari respondennya pasti akan melakukan transaksi online pada saat mereka merasa terlindungi dari sisi privasi dan keamanan. Temuan ini diperkuat oleh Hoffman and Novak (2000), Reichheld and Schefter (2000), dan Chung and Shin (2010) yang berpendapat bahwa keamanan bertransaksi dalam sistem belanja online menjadi faktor penting untuk menarik pelanggan, mengingat keamanan sebuah situs ritel yang akan berpengaruh pada kepuasan pelanggan. Berdasarkan fenomena tersebut, penelitian ini menghipotesakan:

$\mathrm{H}_{4}$ : Keamanan ritel online akan memiliki efek positif terhadap kepuasan pelanggan.

\section{Komunikasi}

Komunikasi dapat didefinisikan sebagai berbagi informasi yang sesuai dan berarti baik secara formal maupun informal (Anderson and Narus, 1990). Paling tidak ada tiga aspek kunci dalam komunikasi yaitu keterbukaan, kualitas informasi, kualitas respon (Mukherjee and Nath, 2003). Keterbukaan sebagai salah satu aspek moralitas yang baik dari seseorang atau sebuah organisasi dapat membangun kepercayaan pihak lain. Gefen and Straub (2001) menemukan bahwa komunikasi manusia dengan mesin, atau setidaknya kepercayaan bahwa sistem elektronik mempunyai karakteristik sosial, sangat penting untuk membangun kepercayaan konsumen online. Kemampuan sebuah situs memenuhi kebutuhan pelanggannya terkait dengan seberapa jauh situs tersebut mampu meningkatkan komunikasi social dalam bentuk keterbukaan, penyediaan informasi yang autentik, relevan, dan berkualitas, serta sistem umpan balik yang memadai. Kualitas informasi diukur dari tingkat ke-autentik-an, relevan, dank ke-lengkap-an informasi yang dalam penelitian ini merujuk pada keinformatifan. Sedangkan kualitas respon mengacu pada kecepatan dan frekuensi dalam merespon komunikasi yang terjadi.

Joines et al. (2003) menunjukkan bahwa kecenderungan pengguna internet untuk melakukan belanja online berhubungan dengan motivasi komunikasi. Lebih jauh Chung and Shin (2010) mempertegas bahwa komunikasi mendorong terciptanya kepuasan pelanggan. Sehingga penelitian ini mengajukan hipotesa:

\section{$\mathrm{H}_{5}$ : Komunikasi bisnis ritel online akan memiliki efek positif terhadap kepuasan.}

\section{Kepuasan Konsumen}

Terdapat banyak definisi mengenai kepuasan pelanggan. Kotler (2003) mendefinisikan kepuasan pelanggan sebagai perasaan suka atau tidak suka seseorang terhadap suatu produk setelah membandingkan kinerja produk tersebut dengan yang diharapkan. Sementara Johnson and Fornell (1991) menyatakan bahwa kepuasan konsumen merupakan hasil evaluasi menyeluruh konsumen atas kinerja produk yang dikonsumsinya. Dalam kontek pemasaran jasa, kepuasan dapat didefinisikan sebagai kondisi afektif pelanggan sebagai akibat evaluasi global dari seluruh aspek yang menciptakan hubungan pelanggan dengan penyedia jasa (Casalo et al., 2008)

Dalam beberapa dekade terakhir, kepuasan konsumen selalu menjadi fokus perhatian para akademisi dan praktisi pemasaran. Perhatian tersebut berasal dari sebuah filosofi yang menyatakan bahwa untuk mencapai kesuksesan perusahaan tergantung pada kemampuan perusahaan tersebut dalam memberikan apa yang diinginkan konsumennya. 
Dengan kata lain, kepuasan konsumen merupakan kunci sukses perusahaan (Kurtz and Clow, 1993). Lebih lanjut, Shin and Elliot (1998) menjelaskan bahwa kepuasan konsumen menciptakan retensi konsumen (consumer retention) yang selanjutnya dapat meningkatkan keuntungan perusahaan, mengingat biaya untuk mempertahankan konsumen yang sudah ada lebih murah daripada biaya mencari konsumen baru.

Dalam konteks bisnis retail online, lebih spesifik Horppu et al. (2008) menyatakan bahwa kepuasan situs web memiliki efek positif terhadap kepercayaan situs web. Kepuasan yang sedang berlangsung menumbuhkan kepercayaan, yang merupakan hasil dari kepuasan yang konsisten dengan transaksi-transaksi individual dari waktu ke waktu (Hess and Story, 2005). Kombinasi kepuasaan dan kepercayaan merupakan kondisi yang memfasilitasi terbentuknya hubungan jangka panjang dengan pelanggan yang bercirikan sebuah komitmen (Fullerton, 2003; Morgan and Hunt; 1999).

Kepuasan tidak hanya mendorong kecenderungan perilaku konsumen untuk melakukan pembelian ulang tetapi juga mendorong mereka untuk melakukan positive word of mouth (Reicheld dan Sasser, 1990; Boulding et al., 1993). Kepuasaan terhadap karakteristik situs dalam belanja online mempengaruhi komitmen (e-commitment) karena kepercayaan (e-trust) dan komitmen merupakan dua faktor yang saling berinteraksi, dan kemudian mendorong terjadinya komunikasi Word of Mouth (WOM) (Mukherjee and Nath, 2007).

Berdasarkan uraian diatas, penelitian ini mengajukan hipotesa:

$\mathrm{H}_{6}$ : Kepuasan pelanggan akan memiliki efek positif terhadap komitmen.

$\mathrm{H}_{7}$ : Kepuasaan pelanggan akan memiliki efek positif terhadap komunikasi WOM.

\section{Komitmen}

Temuan empiris menunjukkan bahwa komitmen merupakan faktor kunci dalam membangun dan mempertahankan hubungan dengan pihak lain (Cater and Zabkar, 2008). Komitmen melambangkan jaminan implisit maupun eksplisit dari penyedia layanan, mengacu terhadap kesediaan untuk mengembangkan dan mempertahankan hubungan pertukaran yang positif. Moorman et al. (1992) lebih menekankan definisi komitmen dari unsur perilaku sebagai berikut: "Commitment to the relationship is desire to maintain a value relationship". Definisi ini menekankan pentingnya "value relationship" dikaitkan dengan suatu keyakinan bahwa tidak akan terjadi suatu komitmen, apabila salah satu pihak atau kedua-duanya merasa bahwa keuntungan itu tidak begitu penting. Komitmen, dalam suatu pertukaran berbasis hubungan (relational exchange), merupakan pengendali bagi semua pertukaran antara perusahaan dengan berbagai pihak (Morgan and Hunt, 1994).

Dalam bisnis ritel online Mukherjee and Nath (2007) mendefinisikan komitmen sebagai bentuk asosiasi dan rasa memiliki seperti halnya komitmen afektif. Komitmen afektif bersumber dari perasaan dan preferensi positif terhadap sesbuah objek yang seringkali bermuara pada kemitraan jangka panjang (Wu et al., 2009). Mukherjee and Nath (2007) menunjukkan bahwa $e$-trust berpengaruh positif e-commitment dan e-commitment memiliki efek positif terhadap niat perilaku seperti komunikasi word of mouth (WOM), niat pembelan, dan interaksi lanjutan. Temuan ini dipertegas oleh penelitian Chung and Shin (2010) yang membuktikan bahwa komitmen mendorong terjadinya komunikasi WOM Hal ini menjadi bukti empiris dari pendapat Dick dan Basu (1994) yang menyatakan bahwa konsekuensi potensial dari sebuah komitmen dapat menimbulkan suatu komunikasi word-ofmouth

$\mathrm{H}_{8}$ : Komitmen akan memiliki efek positif terhadap komunikasi WOM

\section{Komunikasi Word of Mouth (WOM)}

Komunikasi WOM adalah komunikasi dari orang ke orang antara penerima dan pemberi pesan dimana penerima pesan menganggap pesan tentang merek, produk atau jasa yang disampaikan bukan merupakan pesan komersial (Arndt, 1967). Komunikasi ini merupakan sebuah fenomena kelompok, sebuah pertukaran pemikiran atau ide antara dua orang atau lebih (Bone, 1992). Ringen (1987) mengungkapkan bahwa kegiatan WOM mempengaruhi berbagai macam kondisi pembelian konsumen seperti kesadaran akan merek atau produk, harapan, persepsi, sikap, perilaku, dan niat beli. 
Komunikasi WOM mempermudah konsumen dalam memutuskan pembelian karena komunikasi tersebut dapat mengurangi resiko kegagalan dalam pembelian dan meminimalkan usaha pencarian informasi. Konsumen pada umumnya tidak mampu memproses semua informasi yang tersedia untuk memutuskan pembelian. Mereka cenderung menggunakan pedoman yang sederhana untuk memudahkan pencarian informasi dan pengambilan keputusan pembelian. Hal ini mereka dapatkan melalui komunikasi WOM (Duhan et al., 1997). Oleh karenanya komunikasi WOM lebih dipercaya daripada iklan, atau informasi yang disediakan perusahaan melalui promosi (Silverman, 2001).

Dalam bisnis online, WOM yang terjadi adalah bentuk komunikasi secara tidak langsung atau melalui media internet yang disebut sebagai electronic-WOM (e-WOM). EWOM mempengaruhi kinerja bisnis, mengingat e-WOM berpengaruh dalam pengadopsian pendapat online, inovasi layanan, dan dalam menentukan pilihan produk (Cheung et al., 2008). Konsumen sering bergantung pada WOM untuk mengurangi resiko dan ketidakpastian yang dirasakan berhubungan dengan pengambilan keputusan pelayanan (Mangold et al, 1999).

\section{Kerangka Konseptual Penelitian}

Berdasarkan hipotesa-hipotesa diatas maka kerangka konseptual penelitian ini dapat digambarkan dalam Gambar 1.

\section{METODOLOGI PENELITIAN}

Obyek penelitian ini adalah bisnis penjualan online, khususnya konsumen yang pernah melakukan pembelian produk secara online. Populasi dalam penelitian ini adalah masyarakat Indonesia yang mempunyai pengalaman pembelian produk melalui internet. Mengingat populasi penelitian ini sangat luas, maka peneliti membatasi daerah penelitian ini di Daerah Istimewa Yogyakarta. Sampel sebanyak 300 yang telah sesuai dengan batas minimal sampel dalam uji Structural Equation Modeling (SEM) (Hair et. al, 1998).

Pengumpulan data penelitian dilakukan dengan menggunakan kuesioner yang merupakan adaptasi dari istrumen penelitian yang telah dipergunakan oleh Chung and Shin (2010). Sebelum pengumpulan data dilakukan kuesioner terlebih dahulu diuji validitas dan reliabilitasnya, dengan menggunakan 35 orang responden yang tidak disertakan dalam analisa data. Sebuah indikator dikatakan valid jika mempunyai nilai corrected item total corellation $\geq 0.30$. Pengukuran sebuah vareabel dikatakan reliabel jika mempunyai nilai Cronbach Alpha $\geq 0.60$.

Berdasarkan uji validitas dan reliabilitas terdapat dapat dua pernyataan yang tidak valid yaitu satu pada variabel dimensi kenyamanan dan satu pada variabel desain situs. Sedangkan pernyataan-pernyataan lain pada setiap variabel valid dan reliabel dalam penelitian ini. Secara lebih rinci pernyataan dari masing-masing variabel tersebut dan hasil uji validitas dan reliabilitasnya dapat dilihat pada Tabel 1.

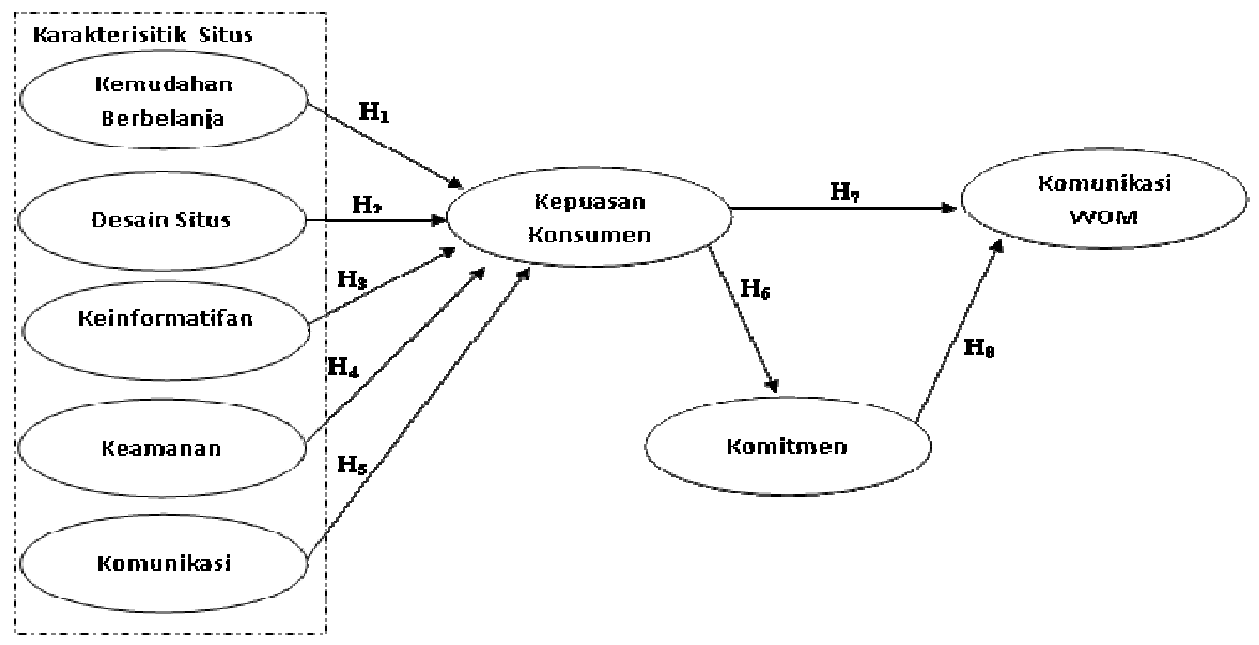

Gambar 1: Kerangka Konseptual Penelitian 
Tabel 1: Hasil Uji Validitas dan Reliabilitas Instrument Penelitian

\begin{tabular}{|c|c|c|c|}
\hline Variabel / Indikator & $\begin{array}{c}\text { Corrected } \\
\text { Item-Total } \\
\text { Correlation }\end{array}$ & $\begin{array}{l}\text { Cronbach's } \\
\text { Alpha }\end{array}$ & Status \\
\hline Karakteristik situs: Kemudahan & & 0.730 & Reliabel \\
\hline Situs ini sangat nyaman untuk digunakan & 0.540 & & Valid \\
\hline Dibutuhkan waktu yang singkat untuk berbelanja di situs ini & 0.527 & & Valid \\
\hline Situs ini menyediakan kemudahan prosedur pemesanan & 0.480 & & Valid \\
\hline $\begin{array}{l}\text { Orang yang melakukan pembelian pertama kali pada situs ini } \\
\text { tidak memerlukan bantuan }\end{array}$ & 0.287 & & Tidak Valid \\
\hline Karakteristik situs: Desain Situs & & 0.725 & Reliabel \\
\hline Situs ini menarik secara visual & 0.467 & & Valid \\
\hline Situs ini memiliki konten pilihan yang baik & 0.488 & & Valid \\
\hline Tampilan situs yang dimiliki professional & 0.667 & & Valid \\
\hline Desain ini mudah dipahami dalam melakukan transaksi & 0.290 & & \\
\hline Karakteristik situs: Keinformatifan & & 0.883 & Reliabel \\
\hline $\begin{array}{l}\text { Menyediakan informasi yang lengkap tentang fitur dan buku } \\
\text { yang dijual }\end{array}$ & 0.657 & & Valid \\
\hline $\begin{array}{l}\text { Memberikan informasi yang akurat tentang fitur dan kualitas } \\
\text { produk }\end{array}$ & 0.849 & & Valid \\
\hline $\begin{array}{l}\text { Memberikan berbagai jenis informasi (pembayaran, } \\
\text { pengiriman, dan pengembalian) }\end{array}$ & 0.624 & & Valid \\
\hline $\begin{array}{l}\text { Menyediakan informasi yang baik tentang produk yang } \\
\text { ditawarkan }\end{array}$ & 0.550 & & Valid \\
\hline Karakteristik situs: Keamanan & & 0.801 & Reliabel \\
\hline Saya merasa nyaman dalam bertransaksi ini & 0.489 & & Valid \\
\hline Privasi saya dilindungi di situs ini & 0.764 & & Valid \\
\hline $\begin{array}{l}\text { Saya percaya bahwa situs ini tidak akan menyalah gunakan } \\
\text { informasi pribadi saya }\end{array}$ & 0.591 & & Valid \\
\hline $\begin{array}{l}\text { Saya percaya bahwa situs ini tidak akan memberikan } \\
\text { informasi pribadi saya ke situs lain tanpa seijin saya }\end{array}$ & 0.631 & & Valid \\
\hline Karakteristik situs: Komunikasi & & 0.787 & Reliabel \\
\hline Konsumen dapat mengajukan ide atau keluhan pada situs ini & 0.584 & & Valid \\
\hline Situs ini memiliki syarat dan ketentuan yang baik & 0.525 & & Valid \\
\hline Pelanggan dapat mereview produk di situs ini secara aktif & 0.749 & & Valid \\
\hline $\begin{array}{l}\text { Situs ini memberikan kebebasan pada pelanggannya untuk } \\
\text { saling bertukar pikiran }\end{array}$ & 0.564 & & Valid \\
\hline Kepuasan Konsumen & & 0.867 & Reliabel \\
\hline Saya puas dengan tawaran yang tersedia di situs ini & 0.669 & & Valid \\
\hline Saya puas dengan pembelian yang dilakukan di situs ini & 0.839 & & Valid \\
\hline Saya puas dengan produk yang saya beli di situs ini & 0.763 & & Valid \\
\hline Komitmen & & 0.833 & \\
\hline Saya merasa situs ini layaknya seoang teman & 0.430 & & Valid \\
\hline Saya merasa situs ini sebagai bagian dari hidup saya & 0.846 & & Valid \\
\hline Saya merasa tidak bisa dipisahkan dengan situs ini & 0.798 & & Valid \\
\hline Saya merasa memiliki situs ini & 0.723 & & Valid \\
\hline Komunikasi Word of Mouth (WOM) & & 0.852 & Reliabel \\
\hline $\begin{array}{l}\text { Saya selalu mengatakan hal yang positif tentang situs ini } \\
\text { kepada orang lain }\end{array}$ & 0.760 & & Valid \\
\hline $\begin{array}{l}\text { Saya merekomendasikan situs ini kepada orang yang meminta } \\
\text { saran tentang situs kepada saya }\end{array}$ & 0.839 & & Valid \\
\hline $\begin{array}{l}\text { Saya mengatakan hal positif tentang produk yang ditawarkan } \\
\text { situs ini }\end{array}$ & 0.734 & & Valid \\
\hline
\end{tabular}


HASIL PENELITAN DAN PEMBAHASAN

Seperti yang telah dijelaskan di awal bahwa responden yang terlibat dalam penelitian dan layak untuk analisa lebih lanjut berjumlah 300 responden. Selanjutnya, peneliti menggunakan Structural Equation Modelling (SEM) dan program AMOS Ver. 6 dalam menganalisa kerangka konseptual penelitian ini. Sebelum menguji hipotesa, terlebih dahulu dilakukan uji validitas dan reliabilitas data yang akan dianalisa. Program AMOS Ver. 6 menyediakan fasilitas menilai validitas konvergen dengan mencermati critical value atau $t$ value dari setiap indikator. Kriterianya adalah apabila $t$ value indikator $\geq 1.96$ maka indikator tersebut signifikan pada tingkat $\alpha=0,05$ (HolmesSmith, 2001). Berdasarkan persyaratan tersebut semua indikator atau item pertanyaan valid dan reliabel dalam mengukur variabelnya yang dapat dilihat di Tabel 2.

Selanjutnya, dengan data yang valid dan reliabel tersebut peneliti melakukan analisa struktural untuk menguji hipotesa menggunakan Program AMOS Ver. 6. Pengaruh variabel eksogen terhadap variable endogen dan nilai $t$ dari masing-masing pengaruh nampak seperti pada Gambar 2.

Tabel 2: Hasil Uji Validitas dan Reliabilitas Data

\begin{tabular}{|c|c|c|c|c|c|}
\hline Indikator & $\lambda_{\mathrm{i}}$ & $\varepsilon_{\mathrm{i}}$ & $t_{\text {value }}$ & $\begin{array}{l}\text { Composite } \\
\text { Reliability }\end{array}$ & Keterangan \\
\hline Kemudahan & & & & 0,765 & Reliabel \\
\hline Ky1 & 0.714 & 0.159 & 1 & & Valid \\
\hline Ky2 & 0.800 & 0.196 & 14.025 & & Valid \\
\hline Ky3 & 0.576 & 0.179 & 14.893 & & Valid \\
\hline Desain Situs & & & & $\mathbf{0 , 8 9 7}$ & Reliabel \\
\hline Ds 1 & 0.658 & 0.090 & 13.815 & & Valid \\
\hline Ds2 & 0.778 & 0.087 & 15.323 & & Valid \\
\hline Ds 3 & 0.967 & 0.143 & 1 & & Valid \\
\hline Keinformatifan & & & & $\mathbf{0 , 9 7 3}$ & Reliabel \\
\hline Inf1 & 0.648 & 0.184 & 16.860 & & Valid \\
\hline Inf2 & 1.046 & 0.158 & 9.782 & & Valid \\
\hline Inf3 & 0.578 & 0.079 & 17.472 & & Valid \\
\hline Inf4 & 0.692 & 0.088 & 1 & & Valid \\
\hline Keamanan & & & & 0,829 & Reliabel \\
\hline $\mathrm{Km} 1$ & 0.606 & 0.166 & 16.567 & & Valid \\
\hline $\mathrm{Km} 2$ & 0.912 & 0.126 & 17.084 & & Valid \\
\hline $\mathrm{Km} 3$ & 0.637 & 0.148 & 20.573 & & Valid \\
\hline $\mathrm{Km} 4$ & 0.712 & 0.121 & 1 & & Valid \\
\hline Komunikasi & & & & 0,767 & Reliabel \\
\hline Kom1 & 0.694 & 0.192 & 10.474 & & Valid \\
\hline Kom2 & 0.591 & 0.113 & 12.827 & & Valid \\
\hline Kom3 & 0.923 & 0.141 & 12.514 & & Valid \\
\hline Kom4 & 0.606 & 0.223 & 1 & & Valid \\
\hline Kepuasan & & & & 0,878 & Reliabel \\
\hline Puas1 & 0.706 & 0.090 & 1 & & Valid \\
\hline Puas2 & 0.970 & 0.137 & 18.284 & & Valid \\
\hline Puas3 & 0.821 & 0.116 & 18.449 & & Valid \\
\hline Komitmen & & & & 0,849 & Reliabel \\
\hline Komit1 & 0.709 & 0.172 & 1 & & Valid \\
\hline Komit2 & 0.956 & 0.121 & 13.671 & & Valid \\
\hline Komit3 & 0.886 & 0.134 & 13.348 & & Valid \\
\hline Komit4 & 0.752 & 0.199 & 12.364 & & Valid \\
\hline WOM & & & & 0,899 & Reliabel \\
\hline Wom1 & 0.815 & 0.116 & 1 & & Valid \\
\hline Wom2 & 0.948 & 0.093 & 15.018 & & Valid \\
\hline Wom3 & 0.787 & 0.087 & 14.593 & & Valid \\
\hline
\end{tabular}

Sumber: Data Primer Diolah 


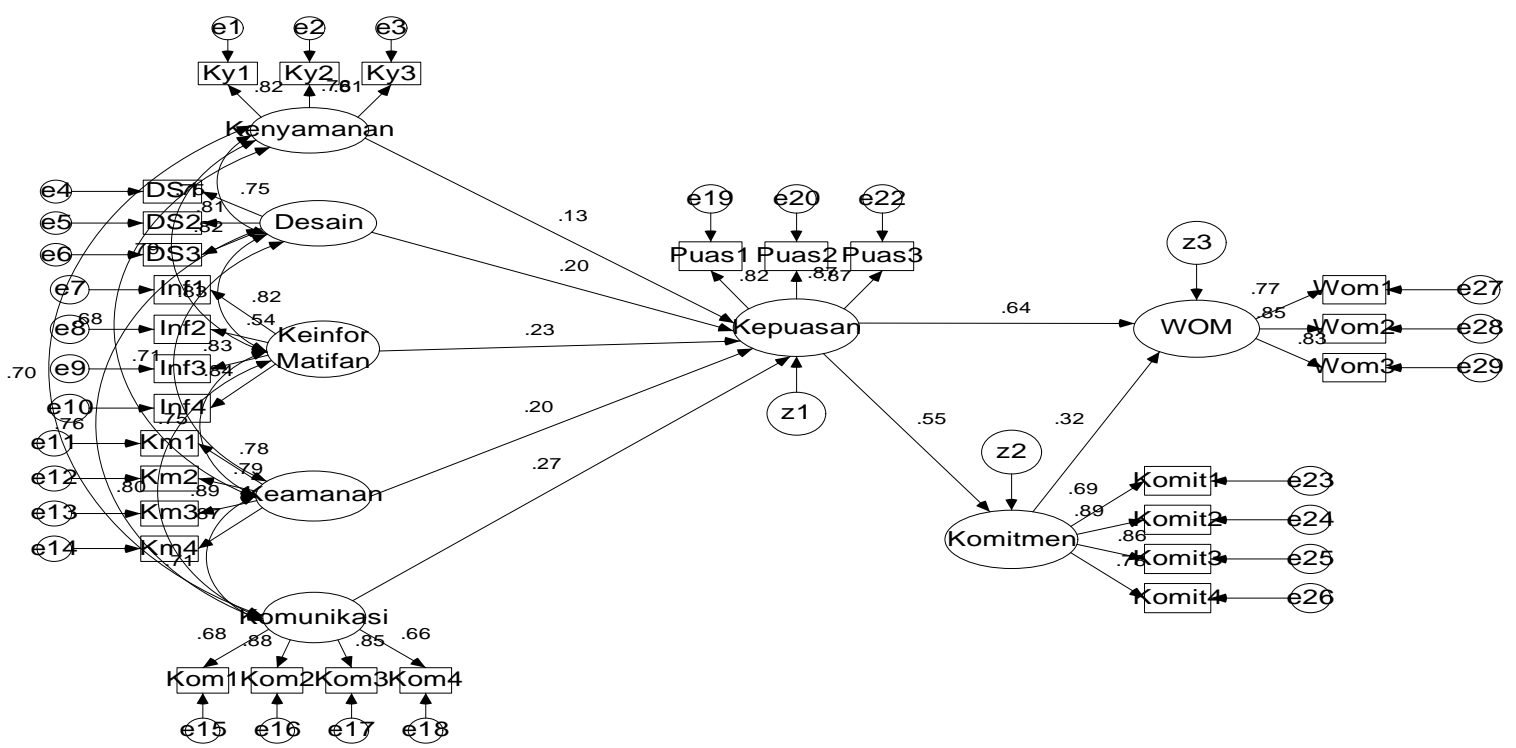

Gambar 2: Model Structural Equation Modeling

Tabel 3: Ringkasan Pengujian Hipotesa

\begin{tabular}{|c|c|c|}
\hline Hipotesa & $\begin{array}{c}\beta \text { or } \gamma \\
(t \text {-value/Signifikansi) }\end{array}$ & Kesimpulan \\
\hline $\begin{array}{l}\mathrm{H}_{1} \text { : Kemudahan belanja ritel online akan memiliki efek } \\
\text { positif pada kepuasan pelanggan. }\end{array}$ & $0,13(1,99 / 4 \%)$ & Terbukti \\
\hline $\begin{array}{l}\mathrm{H}_{2} \text { : Desain situs ritel online akan memiliki efek positif } \\
\text { pada kepuasan pelanggan. }\end{array}$ & $0,20(2,47 / 1 \%)$ & Terbukti \\
\hline $\begin{array}{l}\mathrm{H}_{3}: \text { Keinformatifan ritel online akan memiliki efek } \\
\text { positif pada kepuasan pelanggan. }\end{array}$ & $0,22(2,38 / 1 \%)$ & Terbukti \\
\hline $\begin{array}{l}\mathrm{H}_{4} \text { : Keamanan ritel online akan memiliki efek positif pada } \\
\text { kepuasan pelanggan }\end{array}$ & $0,20(3,54 / 0,0 \%)$ & Terbukti \\
\hline $\begin{array}{l}\mathrm{H}_{5} \text { : } \text { Komunikasi bisnis ritel online akan memiliki efek } \\
\text { positif pada kepuasan pelanggan }\end{array}$ & $0,27(3,86 / 0,0 \%)$ & Terbukti \\
\hline $\begin{array}{l}\mathrm{H}_{6}: \text { Kepuasan pelanggan akan memiliki efek positif pada } \\
\text { komitmen. }\end{array}$ & $0,54(8,10 / 0,0 \%)$ & Terbukti \\
\hline $\begin{array}{l}\mathrm{H}_{7} \text { : Kepuasaan pelanggan akan memiliki efek positif } \\
\text { pada WOM }\end{array}$ & $0,63(9,95 / 0,0 \%)$ & Terbukti \\
\hline $\mathrm{H}_{8}:$ Komitmen akan memiliki efek positif pada WOM. & $0,31(5,50 / 0,0 \%)$ & Terbukti \\
\hline
\end{tabular}

Adapun signifikansi pengaruh antar variabel dan pengujian hipotesa penilitian nampak pada Tabel 3. Berdasarkan Tabel 3 diatas, dari delapan hipotesa yang dibangun pada penelitian ini semuanya terbukti. Hal ini ditunjukkan dengan $t$ value dan tingkat signifikansi dari masing-masing regresi yang lebih besar dari nilai minimumnya yaitu 1,96 dan 5\%. Secara keseluruhan, hal ini menunjukkan bahwa ada pengaruh antara karakteristik situs dengan kepuasan pelanggan atau konsumen yang kemudian hal ini membangun komitmen pelanggan serta menciptakan komunikasi WOM diantara mereka. Hasil penelitian ini konsisten dengan temuan Chung and Shin (2010) dan Mukherjee and Nath (2007) yang menyatakan bahwa kepuasaan terhadap karakteristik situs dalam belanja online mempengaruhi komitmen karena kepercayaan dan komitmen merupakan dua faktor yang saling berinteraksi. Kemudian, kepuasan pelanggan tersebut akan mendorong terjadinya komunikasi Word of Mouth (WOM).

Karakteristik situs yang berupa kemudahan dalam berbelanja, desain situs, keinformatifan, keamanan, dan komunikasi mempunyai pengaruh positif signifikan terhadap kepuasan pelanggan. Koefiesien regresi kemudahan terhadap kepuasan sebesar 0,13 dengan tingkat signifikansi $4 \%$ menunjukkan bahwa hipotesa pertama $\left(\mathrm{H}_{1}\right)$ terbukti. Kemudahaan berbelanja adalah salah satu alasan konsumen 
untuk berbelanja online. Berbelanja online juga dapat menghemat waktu dan usaha yang harus dikeluarkan konsumen. Hal ini sesuai dengan temuan Szymaski and Hise (2000) yang menunjukkan bahwa kepuasaan konsumen meningkatkan ketika mereka merasakan kemudahan dalam berbelanja. Kemudian, desain situs sebagai tampilan fisik dari toko ritel online juga berpengaruh positif signifikan terhadap kepuasan pelanggan. Dengan nilai koefisien regresi sebesar 0,20 dan tingkat signifikansi $1 \%$ menunjukkan bahwa hipotesa kedua $\left(\mathrm{H}_{2}\right)$ terbukti. Responden menyetujui situs ritel online menarik secara visual, memiliki konten pilihan yang baik, tampilan situs yang dimiliki profesional, dan desain mudah dipahami dalam melakukan transaksi. Desain Situs yang berfungsi sebagai lingkungan fisik toko, akan membawa efek positif terhadap belanja konsumen dan meningkatkan kepuasan konsumen. Szymanski and Hise (2000) menyatakan bahwa navigasi, informasi produk, dan desain situs sangat penting terhadap e-satisfaction. Hasil penelitian ini mendukung penelitian yang dilakukan oleh Page and Lepkowska-Whitc (2002), Ranganathan and Ganapathy (2002), Szyminski and Hise (2000), Loshe and Spiller (1998) yang menyatakan bahwa ada pengaruh desain situs pada kepuasan pelanggan.

Karakteristik situs yang lain seperti keinformatifan, keamanan, dan komunikasi juga telah terbukti berpengaruh terhadap kepuasan. Keinfomatifan dengan nilai regresi 0,22 dan tingkat signifikansi $1 \%$ menunjukkan bahwa hipotesa ketiga $\left(\mathrm{H}_{3}\right)$ telah terbukti. Res ponden menyetujui bahwa keinformatifan ritel online menyediakan informasi yang lengkap tentang fitur dan buku yang di jual, memberikan informasi yang akurat tentang fitur dan kualitas produk, menyediakan berbagai jenis informasi (pembayaran, pengiriman dan pengembalian), dan menyediakan informasi yang baik tentang buku. Informasi berkualitas tinggi telah lama ditemukan berasosiasi dengan menggunakan sistem, kepuasan konsumen, dan manfaat (DeLone and McLean, 2003). Selanjutnya, Kateranttanakul (2002) menyatakan bahwa keandalan konten website memfasilitasi konsumen untuk melihat lebih rendah risiko, justifikasi yang lebih baik untuk keputusan mereka dan kemudahan dalam mencapai keputusan yang optimal, dan pada gilirannya mempengaruhi kepuasan pelanggan dan niat untuk membeli secara online. Hasil penelitian ini juga mendukung hasil penelitian Janda et al. (2002) dan Szymanski and Hise (2000) yang menyatakan bahwa kualitas informasi adalah faktor penting dari kepuasan konsumen dalam belanja online.

Keamanan dan komunikasi terbukti mempunyai berpengaruh terhadap kepuasan pelanggan. Dengan hasil regresi dan tingkat signifikansi keamanan sebesar 0,20 dan $0,0 \%$ dan hasil regresi dan tingkat signifikansi komunikasi sebesar 0,27 dan $0,0 \%$. Hal ini menunjukkan bahwa hipotesa keempat dan kelima $\left(\mathrm{H}_{4}\right.$ dan $\left.\mathrm{H}_{5}\right)$ terbukti. Alasan mengapa kecil kemungkinan bagi konsumen untuk melakukan pembelian online adalah rasa khawatir mengenai konsekuensi-konsekuensi dari pemberian informasi pribadi termasuk data kartu kredit kepada para pemasar online. Penelitian dari Belanger et al. (2002) menemukan bahwa kehadiran fitur keamanan pada situs e-commerce adalah penting bagi konsumen, dan membahas bagaimana masalah keamanan konsumen dapat dialamatkan oleh perlindungan teknologi serupa sebagai orangorang bisnis, seperti enkripsi dan otentikasi. Hasil penelitian ini mendukung hasil penelitian sebelumnya yang menyatakab jika sistem transaksi online dan perlindungan privasi berpengaruh terhadap kepuasan pelanggan dalam pembelian online (Udo, 2001; Hoffman and Novak, 2000; dan Reichheld and Schefter, 2000).

Komunikasi terbukti juga berpengaruh terhadap kepuasan pelanggan, dengan hasil regresi 0,27 dan tingkat signifikansi $0,0 \%$ yang menunjukkan bahwa hipotesa kelima $\left(\mathrm{H}_{5}\right)$ terbukti. Responden menyetujui bahwa situs memiliki syarat dan ketentuan yang baik, pelanggan dapat mereview produk di situs ini secara aktif, dan situs ini memberi kebebasan kepada pelanggannya untuk saling bertukar pikiran. Gefen and Straub (2001) menemukan bahwa komunikasi manusia dengan mesin, atau setidaknya kepercayaan bahwa sistem elektronik mempunyai karakteristik sosial, sangat penting untuk membangun kepercayaan konsumen online. Kemudian, Mukherjee dan Nath (2003) menyatakan tahap dimana suatu website dapat mempertinggi komunikasi sosialnya yang meliputi keterbukaan (openness), kecepatan dalam merespon (speed of response) dan kualitas informasi (quality of information) akan 
mempengaruhi kemampuan situs tersebut untuk memenuhi kebutuhan pengguna internet dan berpengaruh terhadap kepuasan penggunanya.

Selanjutnya, kepuasan pelanggan juga terbukti berpengaruh terhadap komitmen dan komunikasi Word of Mouth (WOM). Hasil regresi menunjukkan 0,54 dengan $0,0 \%$ tingkat signifikansi untuk pengaruh kepuasan terhadap komitmen yang berarti bahwa hipotesa keenam $\left(\mathrm{H}_{6}\right)$ terbukti. Kemudian, hasil regresi yang menunjukkan pengaruh kepuasan terhadap komunikasi WOM dalam bisnis ritel online ebesar 0,63 dengan tingkat signifikansi $0,0 \%$, ini berarti bahwa hipotesa ketujuh $\left(\mathrm{H}_{7}\right)$ terbukti. Hasil ini mendukung temuan Mukherjee and Nath (2007) yang menyatakan kepuasaan terhadap karakteristik situs dalam belanja online mempengaruhi komitmen (e-commitment) karena kepercayaan (e-trust) dan komitmen merupakan dua faktor yang saling berinteraksi. Mereka juga berpendapat bahwa kepuasaan tersebut juga mendorong terjadinya komunikasi Word of Mouth (WOM).

Kemudian, komitmen juga berpengaruh terhadap WOM dengan hasil regresi sebesar 0,31 dan tingkat signifikansi $0,0 \%$ yang menunjukkan bahwa hipotesa kedelapan $\left(\mathrm{H}_{8}\right)$ terbukti. Cater and Zabkar (2008) menyatakan, komitmen melambangkan jaminan implisit maupun eksplisit dari penyedia layanan yang mengacu pada kesediaan untuk mengembangkan dan mempertahankan hubungan pertukaran yang positif. Mukherjee and Nath (2007) mendefinisikan komitmen sebagai bentuk asosiasi dan rasa memiliki seperti halnya komitmen afektif. Mereka berpendapat bahwa $e$-trust berpengaruh positif e-commitment dan e-commitment memiliki efek positif terhadap niat perilaku WOM, niat pembelian, dan interaksi lanjutan juga berpengaruh positif niat pembelian secara online. Hasil penelitian ini juga memperkuat temuan Rauyruen and Miller (2007), Cater and Zabkar (2008), dan Chung and Shin (2010) bahwa komitmen yang tinggi akan mendorong terjadinya komunikasi WOM yang positif diantara para pelanggan.

Secara keseluruhan penelitian ini menunjukkan bahwa karakteristik situs sebagai faktor antecedent mempunyai pengaruh pada kepuasan yang kemudian juga menciptakan komitmen dan komunikasi WOM sebagai faktor consequence. Kemudian, kepuasan dan komitmen juga merupakan faktor antecedent yang mendorong consequence berupa komunikasi WOM.

\section{PENUTUP}

\section{Simpulan}

Berdasarkan hasil penelitian dapat ditarik beberapa simpulan sebagai berikut: 1) Antecedents karakteristik situs berupa kemudahan, desain situs, keinformatifan, keamanan, dan komunikasi secara signifikan mempunyai pengaruh terhadap consequence kepuasan pelanggan. Koefisien regresi dan tingkat signifikansi dari masing-masing pengaruh adalah sebagai berikut: Kemudahan - Kepuasan (0,13/4\%); Desain situs - Kepuasan $(0,20 / 1 \%)$; Keinformatifan - Kepuasan $(0,22 / 1 \%)$; Keamanan - Kepuasan $(0,20 / 0,0 \%)$; Komunikasi - Kepuasan (0,27/0,0\%). 2) Antecedent kepuasan mempunyai pengaruh secara signifkan terhadap komitmen dan komunikasi WOM sebagai consequence. Koefisien regresi dan tingkat signifikansi yaitu: Kepuasan - Komitmen $(0,54 / 0,0 \%)$ dan Kepuasan - WOM $(0,63 / 0,0 \%)$. 3)Komitmen sebagai antecedent mempunyai pengaruh signifikan terhadap WOM sebagai consequence. Koefisien regresi dan tingkat signifikansi sebesar 0,31 dan 0,0\%.

\section{Implikasi}

Hasil penelitian ini memberikan implikasi teoritis dan praktis sebagai berikut: 1) Temuan ini membuktikan hubungan antara kepuasan konsumen dalam belanja online dengan penyebab berupa karakteristik situs dan konsekuensi setelahnya berupa komitmen dan komunikasi WOM. Hasil ini konsisten dan memperkuat hasil temuan sebelumnya terutama penelitian yang dilakukan oleh Mukherjee and Nath (2007) bahwa adanya pengaruh antara karakteristik situs dengan kepuasan pelanggan yang kemudian menciptakan komitmen dan mendorong WOM. Secara teoritis, temuan ini menunjukan kemapanan (robustness) dalam menganalisa kepuasan pelanggan dengan faktor penyebab dan faktor konsekuensinya. 2) Bagi praktisi pemasaran, hasil penelitian ini memberikan gambaran dalam pengambilan kebijakan yang berkaitan dengan kepuasan pelanggan dan dalam menciptakan komitmen atau mendorong komunikasi WOM. Peningkatan kemudahan dalam akses atau navigasi 
situs belanja online, pengembangan desain situs, format informasi dalam situs, peningkatan keamanan serta fasilitas komunikasi antar pelanggan adalah hal yang perlu diperhatikan bagi pemasar bisnis ritel online.

\section{Keterbatasan}

Model penelitian ini hanya terbatas pada pembahasan faktor penyebab (antecedents) berupa atribut karakteristik situs yang berupa kemudahan, desain situs, keinformatifan, keamanan, dan komunikasi saja. Pada penelitian berikutnya perlu disertakan atributatribut lain atau atribut tambahan dalam karakteristik situs yang berhubungan dengan kepuasan pelanggan dalam berbelanja online.

\section{DAFTAR PUSTAKA}

Anderson, JC., and JA. Narus. 1990. A model of distributor firm and manufacturer firm working partnership. Journal of Marketing. 54 (1). 42-58

Arndt, J. 1967. Role of Product-Related Conversations in the Diffusion of New Product. Journal of Marketing Research. 4. 291-295.

Barlow, AK., QS. Noreen, and M. Mannion. 2004. Developments in information and communication technologies for retail marketing channels. International Journal of Retail \& Distribution Management. 32 (3). 157-63.

Bone, PF. 1992. Determinants of Word of Mouth Communications during Product Consumption. Advances in Consumer Research. 19. 579 -83

Boulding, W., A. Kalra, R. Staelin, and VA. Zeithaml. 1993. A Dynamic Process Model of Service Quality: From Expectations to Behavioural Intentions. Journal of Marketing Research. 30 (February). 7-27

Casalo, LV., C. Flavian, and M. Guinaliu. 2008. The role of satisfaction and website usability in developing customer loyalty and positive word-of-mouth in the ebanking services. The International Journal of Bank Marketing. 26 (6). 399-417.
Cater, B., and V. Zabkar. 2008. Antecedents and consequences of commitment in marketing research services: the client's perspective. Industrial Marketing Management. 26 (3). 245-54.

Chung, K.H., and JI. Shin. 2008. The relationship among e-retailing attributes, e-satisfaction and e-loyalty. Management Review: An International Journal. 3 (1). 23-45.

Chung, KH., and JI. Shin. 2010. The antecedents and consequents of relationship quality in internet shopping. Asia Pacific Journal of Marketing and Logistics. 22 (4). 473-91.

Cheung, CMK., MKO. Lee, and N. Rabjohn. 2008. The impact of electronic wordof-mouth: The adoption of online opinions in online customer communities. Internet Research. 18 (3). 229-47.

Dick, A.S., and K. Basu 1994. Customer loyalty: toward an integrated conceptual framework. Journal of the Academy of Marketing Science. 22 (2). 99-113

Duhan, DF., SD. Johnson, JB.Wilcox, and GD. Herrel. 1997. Influence of Consumer Use of Word of Mouth Recommendation Sources. Journal of the Academy of Marketing Science. 25. 283-295

Fullerton, G. 2003. When does commitment lead to loyalty?. Journal of Service Research. 5 (May). 333-44.

Gefen, D., and D. Straub. 2001. Managing user trust in $\mathrm{B} 2 \mathrm{C}$ e-services. e-Service Journal. 1 (1). 7-34

Hair, JJF., RE. Anderson, RL. Tatham, and W. C. Black. 1998. Multivariate Data Analysis. New Jersey: Prentice Hall International, Inc.

Hess, J., and J. Story. 2005. Trust-based commitment: multidimensional consumer-brand relationships. Journal of Consumer Marketing. 22 (6). 313-22.

Hoffman, DL. and TP. Novak. 2000. How to acquire customers on the web. Harvard Business Review, May-June. 179-88. 
Holmes-Smith, P. 2001. Introduction to Structural Equation Modeling Using LISREL. Perth: ACSPRI-Winter Training Program.

Horppu, M., O. Kuivalainen, A. Tarkiainen, and H-K. Ellonen. 2008. Online satisfaction, trust and loyalty, and the impact of the offline parent brand. Journal of Product \& Brand Management. 17 (6). 403-13.

Janda, S., PJ. Trocchia, and K.P. Gwinner. 2002. Consumer perceptions of internet retail service quality. International Journal of Service Industry Management. 13 (5). 412-31

Javerpaa, SL., and PA. Todd. 1996. Consumer reaction to electronic shopping on the world wide web. International Journal of Electronic Commerce. 1 (2). 59-88

Johnson, MD. and C. Fornell. 1991. A frame work for comparing customer satisfaction across individuals and product categories. Journal of Economic Psychology. 12 (2). 267-86.

Joines, J., C. Scherer, and D. Scheufele. 2003. Exploring motivation fo consumer web use and their implications for ecommerce. Journal of Consumer Marketing. 20 (2). 90-109

Jun, SE., and KH. Chung. 2006. A study in the factors of internet shopping site affecting customer's e-satisfaction, eloyalty, and repurchasing intention. The Journal of Internet Electronic Research. 6 (2). 133-58.

Klang, M. 2001. Who do you trust? Beyond encryption, secure e-business. Decision Support Systems. 31 (3). 293-302

Kotler, P. 2003. Marketing Management, New Jersey: $11^{\text {th }}$ Ed. Prentice Hall International Edition.

Kurtz, DL., and KE. Clow. 1993. Managing Consumer Expectations on Services. Journal of Marketing Management. 2 (2). 19-25

Lee, MKO., and E. Turban. 2001. A trust model for consumer internet shopping.
International Journal of Electronic Commerce. 6 (1). 75-92

Lohse, GL., and P. Spiller. 1998. Electronic shipping. Communications of the ACM. 41 (7). 81-7.

Madu, CN., and AA. Madu. 2002. Dimensions of e-quality. International Journal of Quality and Reliability Management. 19 (3). 246-58

Mangold, WG., F. Miller, and GR. Brockway. 1999. Word of mouth communication in the service marketplace. The Journal of Service Marketing. 13. 73-87.

Morgan, RM., and SD. Hunt. 1994. The commitment-trust theory of relationship marketing. Journal of Marketing. 58 (3). 20-38.

Morgan, RM., and SD. Hunt. 1999. Relationship-based competitive advantage: the role of relationship marketing inmarketing strategy. Journal of Business Research. 46. 281-90.

Moorman, C., G. Zaltman, and R. Deshpande. 1992. Relationships between providers and users of marketing research: the dynamics of trust within and between organizations. Journal of Marketing Research. 29 (3). 314-29.

Mukherjee, A., and P. Nath. 2003. A model of trust in online relationship banking. International journal of Bank Marketing. 21 (1). 5-15.

Mukherjee, A., and P. Nath. 2007. Role of electronic trust in online retailing: a reexamination of the commitment-trust theory. European Journal of Marketing. 41 (9/10). 1173-202.

Nah, FF-H., and S. Davis. 2002. HCI research issues in e-commerce. Journal of Electronic Commerce Research. 3 (3). 98-113

Page, C., and E. Lepkowska-White. 2002. Web equity: a framework for building consumer value in online companies. Journal of Consumer Marketing. 19 (3). 231-48. 
Pastrick, G. 1997. Secrets of great site design. Internet User. Fall. 80-87

Ranganathan, C., and S. Ganapathy. 2002. Key dimensions of business-to-consumer web sites. Information \& Management. 39. 457-6.

Rauyruen, P., and KE. Miller. 2007. Relationship quality as a predictor of B2B customer loyalty. Journal of Business Research. 60. 21-31.

Reichheld, FF., and P. Schefter. 2000. Eloyalty: your secret weapon on the web. Harvard Business Review. July-August. 105-13.

Reichheld, FF. and WE. Sasser. 1990. Zero Defections: Quality Comes to Services. Harvard Business Review. 68 (September-October). 301-307

Ringen, PH. 1987. A Word of Mouth Network. Advances in Consumer Research, 14. 213-17

Shin, D. and K. Elliot. 1998. Assessing the Impact of Customer Satisfaction on Customer Retention. Journal of Marketing Management. 8 (2). 95-102

Silverman, G. 2001. The Power of Word of Mouth. Direct Marketing, 64. 47-52

Srinivansan, SS., R. Anderson, and K. Ponnavolu. 2002. Customer loyalty in e-commerce: an exploration if its antecedents and consequence. Journal of Retailing. 78 (1). 41-50.

Swaminathan, V., E. Lepkowska-White, and BP. Rao. 1999. Browser or buyers in cyberspace? An investigationof factors influencing electronic exchange. Journal of Computer-Mediated Coтmunication. 5 (2)

Szymanski, DM., \& RT. Hise. 2000. Esatisfaction: an initial examination, Journal of Retailing. 76 (3). 309-22.

Torkzadeh, G., and G. Dillon. 2002. Measuring factors that influence the success of internet commerce. Information Systems Research. 13 (2). 187-204

Udo, GJ. 2001. Privacy and security ecommerce: a survey study. Information Management \& Computer Security. 9 (4). 165-74.

Wixom, BH., and PA. Todd. 2005. A theoritical integration of user satisfaction and technology acceptance. Information Systems Research. 16 (1). $85-102$

Wu, JJ., YH. Chen, and YS. Chung. 2009. Trust factors influencing virtual community members: a study of transaction communities. Journal of Business Research. 63 (9/10). 1025-32. 